\title{
Water Balance Model: Implications for Groundwater Recharge Estimation in Data Scarce Arid Catchment, Northern Ethiopia
}

\author{
Nata T. Tafesse ${ }^{1}$ \\ Michiele Gebrehiwet ${ }^{2}$ \\ Solomon Habtu ${ }^{3}$ \\ Berhanu F. Alemaw ${ }^{4}$
}

${ }^{4}$ Department of Geology, University of Botswana, Botswana

Email: Nata.Tafesse@mopipi.ub.bw

${ }^{-s}$ Department of Land Resources Management and Environmental Protection, Mekelle University, Ethiopia

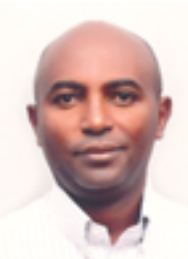

( Corresponding Author)

Abstract

The paper presents results related to water balance model of the Gumselassa catchment (28.1 $\mathrm{km} 2$ ), Tigray, Northern Ethiopia. The catchment includes a small dam called Gumselassa dam having an effective watershed area of $22.14 \mathrm{~km} 2$ with reservoir capacity of $1.92 \times 106 \mathrm{~m} 3$ and command area of about $1 \mathrm{sq} . \mathrm{km}$. The hydrology of the area was characterized on the basis of land use, soil, slope and climatic parameters. Different methods were employed in this study: rainfall coefficient method was used to determine monthly distribution of rainfall; Penman method to calculate evaporation from the reservoir; Thornthwaite method and Thornthwaite water balance model to determine potential and actual evapotranspiration; runoff coefficient method to estimate runoff; and, the water balance model was used to quantify the recharge. The catchment is characterized by one rainy season (three months) and two dry seasons (nine months) during the year. The mean annual rainfall of the catchment is $485.89 \mathrm{~mm}$. The total annual water loss by evaporation from the reservoir is $1263.27 \mathrm{~mm}$. The mean annual actual evapotranspiration of the effective watershed area one and two is $318.57 \mathrm{~mm}$ and $310.27 \mathrm{~mm}$, respectively. The mean annual actual evapotranspiration of the water contributing area 1 and 2 to the command area is $337.06 \mathrm{~mm}$ and $355.29 \mathrm{~mm}$, respectively. The mean annual actual evapotranspiration of the command area is $319.3 \mathrm{~mm}$. The mean annual runoff generated from the effective watershed area one and two is 1.167 and 0.44 million cubic meters, respectively. The mean annual runoff generated from the water contributing area 1 and 2 to the command area is 0.048 and 0.349 million cubic meters, respectively. The mean annual runoff generated from the command area is 0.0875 million cubic meters. The total amount of water which is actually available to recharge the groundwater within the catchment is 4.065 million cubic meters, and any application of water for irrigation from the reservoir should take into account this readily available water.

Keywords: Command area, Evapotranspiration, Recharge, Reservoir, Runoff.

Citation | Nata T. Tafesse; Michiele Gebrehiwet; Solomon Habtu; Berhanu F. Alemaw (2018). Water Balance Model: Implications for Groundwater Recharge Estimation in Data Scarce Arid Catchment, Sciences, $5(1): 34-46$

History:

Received: 10 August 2018

Revised: 17 September 2018

Accepted: 19 October 2018

Published: 23 November 2018

Licensed: This work is licensed under a Creative Commons Attribution 3.0 License (co) EY

Publisher: Asian Online Journal Publishing Group
Contribution/Acknowledgement: All authors contributed to the conception and design of the study.

Funding: This research work was financed by EAU4FOOD project (European Union and African Union cooperative research). The support provided in the form funding is duly acknowledged.

provided in the form funding is duly acknowledged.
Competing Interests: The authors declare that they have no conflict of Competing
interests.

Transparency: The authors confirm that the manuscript is an honest, accurate, and transparent account of the study was reported; that no vital features of the study have been omitted; and that any discrepancies from the study as planned have been explained.

Ethical: This study follows all ethical practices during writing.

\section{Contents}

1. Introduction

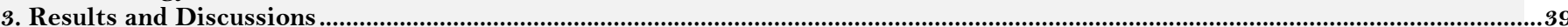

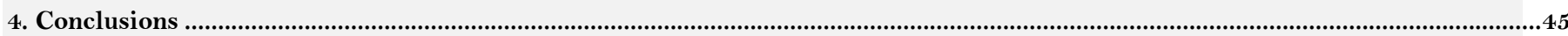




\section{Introduction \\ 1.1. General}

Groundwater recharge is a fundamental component in the water balance of any watershed. Groundwater recharge may be explained as the process whereby the amount of water present in or flowing through the interstices of the sub-soil increases by natural or artificial means. The amount of water that may be extracted from an aquifer without causing depletion is primarily dependent upon the groundwater recharge. Rainfall is the principal source for replenishment of moisture in the soil water system and recharge of groundwater. Other sources include recharge from rivers, streams, reservoirs, irrigation water etc.

Groundwater recharge occurring in small- and large-scale and spatially and temporally is influenced by factors such as climate, soil characteristics, vegetation, geology, slope and thickness of permeable unsaturated zones [1,2]. Because groundwater is such a valuable resource, it is important to understand and know the groundwater recharge for sustainable utilization of this resource. Effective management of groundwater aquifers is heavily influenced by the accurate estimation of recharge. However, the recharge is one of the water cycle components most difficult to quantify accurately as it varies significantly in temporal and spatial dimensions [3-10]. There is no technique for direct measurement of recharge due to the lack of universal standard methods [11]. Nevertheless, numerous methods, ranging widely in complexity and cost, have been used to estimate recharge [6, 12]. These methods involved a variety of approaches, including soil moisture budgeting, well hydrograph analysis, numerical modeling and a catchment water balance [13]. In this study, groundwater recharge estimates based on the water balance model is assessed.

This study is conducted in Gumselasa catchment in the Tigray region, which is the northern most region of Ethiopia. With a total land area of 8 million ha, Tigray is one of the most degraded and drought prone regions of Ethiopia [14]. The frequent dry spells and droughts exacerbate the incidence of crop failure and hence food insecurity and poverty.

Gumselassa catchment includes a small dam called Gumselassa dam. The dam was constructed in 1995 by COSAERT (Commission for Sustainable Agriculture and Environmental Rehabilitation in Tigray) for the purpose of irrigation and was designed to irrigate 120 ha of land [15].

Even though the dam was constructed twenty three years ago, the water balance which takes into account the whole catchment of Gumselasa has not yet been studied. The available outflow, inflow and surplus waters in the effective watershed, reservoir and command area are not determined so far. This research, which makes its objective on determination of recharge in whole catchment of Gumselasa, was conducted to provide quantitative information about the water budget components in the area.

\subsection{Description of the Study Area}

\subsubsection{Location}

Gumselasa catchment is located bounded between $556000-564000 \mathrm{~m} \mathrm{E}$ and $1458000-1467000 \mathrm{~m} \mathrm{~N}$, having an area of 28.1 sq. kms (Fig. 1).

\subsubsection{Physiography and Drainage}

Geomorphologically the study area is dominantly flat to gentle sloping area interrupted in some parts with small dome undulating topography having an orientation of N-S and constituted by dolerite. Chain of mountains made the eastern boundary of the study area. The altitude of the catchment ranges from $2218 \mathrm{~m}$ above mean sea level on the top of the mountain to $2100 \mathrm{~m}$ above sea level at the reservoir point.

The catchment drains by two major perennial streams: Asegeda and Mehombiya rivers (Fig. 2). Asegeda river rises from the eastern mountainous area whereas the Mehombiya river from the southeast mountainous area. Both of them flow to the west, and joined and form one big river. There are also other intermittent streams in the catchment. Generally, the catchment has a dendritic drainage pattern.

As it was mentioned above the catchment area comprises a small dam called Gumselasa dam (Fig. 2). The dam axis has a length of $400 \mathrm{~m}$ and a height of $13.5 \mathrm{~m}$ with a water holding capacity of 1.92 million cubic meters and was designed to irrigate 120 ha of land [15]. Currently the available water in the dam is 0.194 million cubic meters.

\subsubsection{Soil and Land Use}

To investigate soil types of the area, seven pits were drilled in different parts of the catchment, and representative soil samples were taken from each of them for textural study at laboratory. The result indicates that the catchment is found dominated by two types of soil: clay and sandy clay loam. The clay is found covering part of the effective watershed, all the water contributing areas and command area whereas the sandy clay loam is found covering only parts of the effective watershed area on the east and northeast parts of the catchment. Water contributing areas are areas that are found adjacent to the command area that directly contributes water to the command area but not to the dam.

The different land use patterns of the catchment were identified during the fieldwork. Accordingly, cultivated land, grassland, and chain of mountains in the eastern and northeastern, which are mainly bare land, are the major land use patterns of the catchment. Cultivated land constitutes the major portion of the effective watershed area, the whole water contributing areas and the command area. Grassland is found just occupying a small area in the effective watershed parts of the catchment. The major crops cultivated in the area are cereal crops such as wheat, teff, sorghum, maize and barely.

\section{Methodology}

In this study the groundwater recharge of the whole catchment is estimated using water balance model. 


\subsection{Water Balance Model}

The water balance model equation for any natural area (such as a river basin) or water body indicates the relative values of inflow, outflow and change in water storage for the area or water body. In general, the inflow part of the water balance equation comprises precipitation $(\mathrm{P})$ as rainfall and snow actually received at the ground surface, and surface and subsurface water inflow into the basin or water body from outside $\left(Q_{\text {si }}\right.$ and $\left.\mathrm{Q}_{\mathrm{ux}}\right)$.

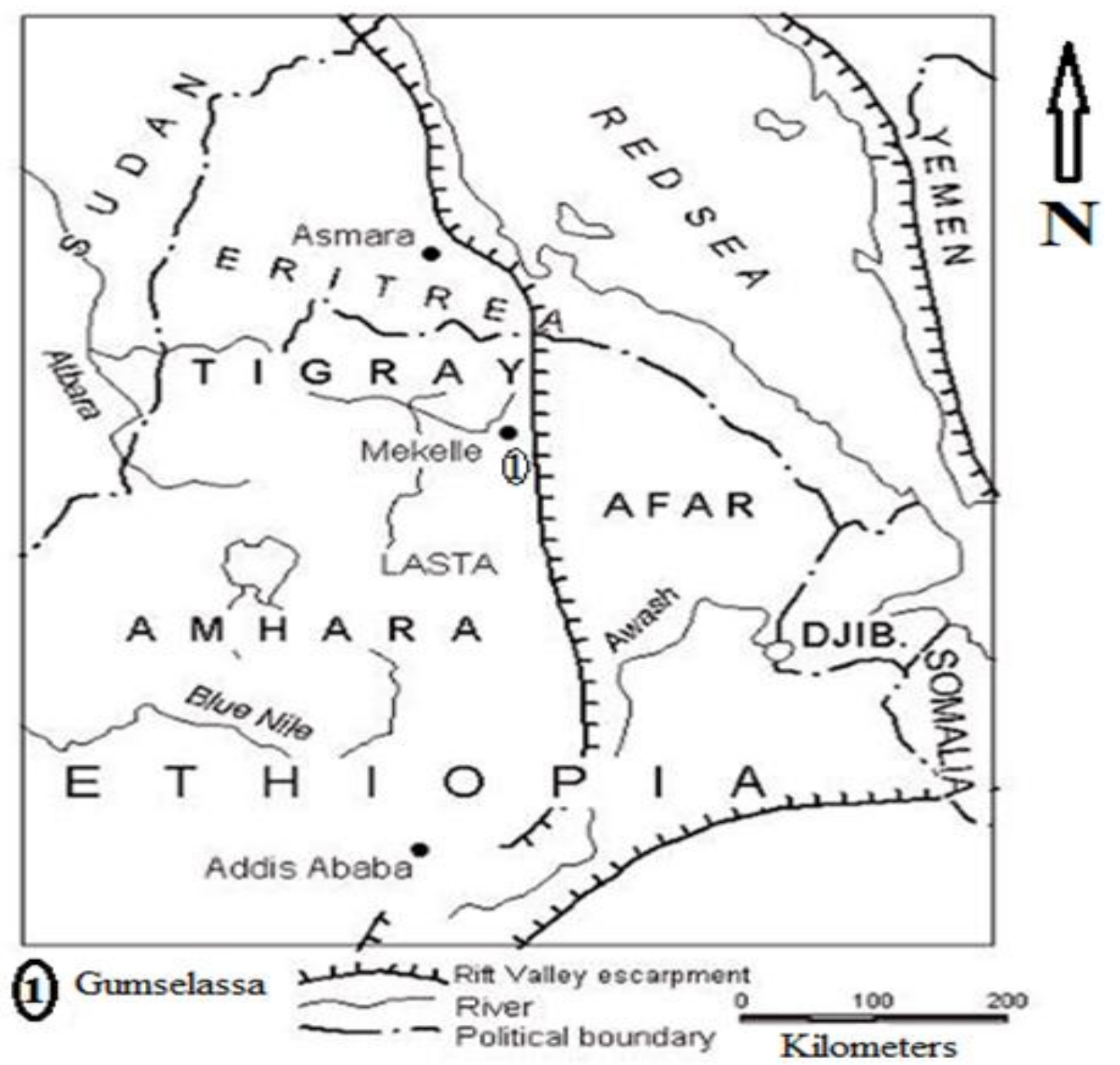

Figure-1. Location map of the study area (Northern Ethiopia bounded in the northwest by Sudan, North and Northeast by Eritrea, and east by Djibouti and Somalia: The Rift valley escarpment is part of the Eastern scarpment of the East African Rift system).

Source: After Nyssen, et al. [16]

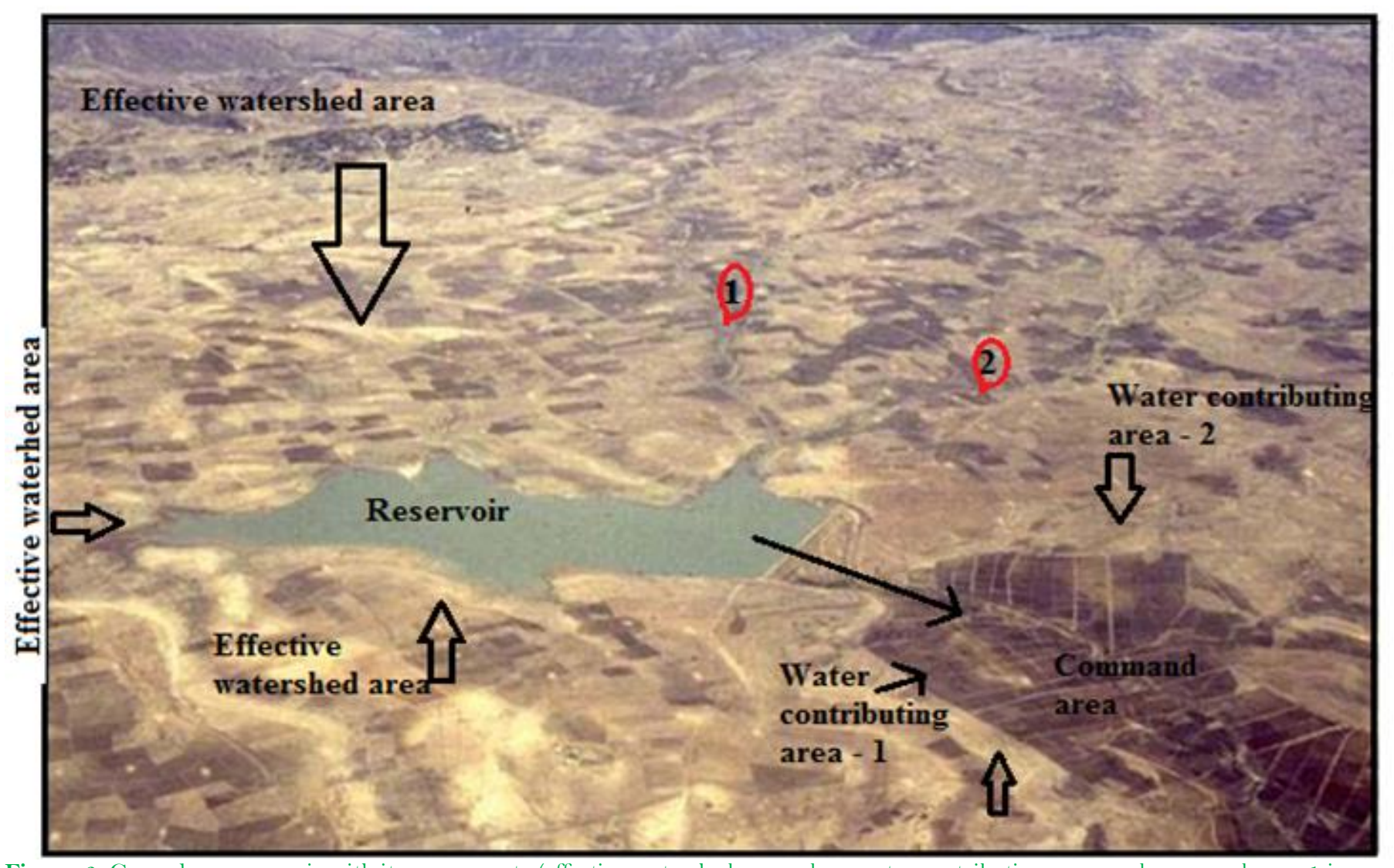

Figure-2. Gumselassa reservoir with its components (effective watershed areas, dam, water contributing areas and command area. 1 is Asegeda river and 2 is Mehombiya river).

Source: Modified after Michiele [17] 
The outflow part of the equation includes evaporation from the surface of the water body (E) and surface and subsurface outflow from the basin or water body $\left(Q_{\text {so }}\right.$ and $\left.Q_{u p}\right)$. When the inflow exceeds the outflow, the total water storage in the body $(\Delta s)$ increases; whereas when an inflow less than the outflow results in decreased storage. Consequently the water balance for any water body and any time interval in its general form may be represented by the following equation [18]:

$$
\mathrm{P}+\mathrm{Q}_{\mathrm{si}}+\mathrm{Q}_{\mathrm{ux}}-\mathrm{E}-\mathrm{Q}_{\mathrm{so}}-\mathrm{Q}_{\mathrm{up}} \pm \Delta \mathrm{s}=\mathrm{O}
$$

For application to a variety of water-balance computations Equation 1 may be simplified or made more complex, depending on the available initial data, the purpose of the computation, the type of body (river basin or artificially separated administrative district, lake or reservoir, etc.), and the dimensions of the water body, its hydrographic and hydrologic features, the duration of the balance time interval, and the phase of the hydrological regime (flood, low flow) for which the water balance is computed.

\subsection{Data Collection}

Boundary delineation of the effective watershed, reservoir, command area and adjacent water contributing areas to the command area was done using Garmin GPS and topographic map with a scale of 1:50,000 as a base map. Maps were prepared using the readings and the topographic map as a base map.

In order to determine the basic hydrologic parameters, meteorological data were collected from two meteorological stations. Due to lack of sufficient meteorological data in the study area besides to the data that were collected from Adigudem meteorological station, which is located in the study area, data from a nearby Mekelle Airport meteorological station was used for this study. Both of them are owned by the National Meteorological Service Agency. For the analysis, rainfall data was collected from Adigudem meteorological station. The remaining climatic data such as temperature, wind speed, humidity and sunshine hours were taken from Mekelle Airport meteorological station. Available relevant reports and thematic maps were also collected from different sources.

For computation of the actual evapotranspiration, the dominant soil types and the respective root depth were determined for the different parts of the catchment. Seven soil samples were collected from the different parts of the catchment to identify the soil types, the field capacity, permanent welting point and available water capacity in the measured root depths. Soil samples were analyzed for grain size, field capacity and permanent wilting point in Mekelle University, Land Resources and Environmental Protection Department soil laboratory.

Seepage flow from the dam was measured daily for three consecutive months by installing rectangular weir at downstream of the dam at the place where the seepage water is concentrated (Fig. 3). The Kinds vaterCarter rectangular weir equation [19] empirical formula was used to compute the daily flow.

$$
Q=C_{e} \frac{2}{3} \sqrt{2 g\left(b+K_{b}\right)\left(h+K_{h}\right)^{\frac{3}{2}}}
$$

Where $Q$ is discharge $\left(\mathrm{L}^{3} / \mathrm{T}\right)$, Ce is discharge coefficient, $g$ is acceleration of gravity $\left(\mathrm{L} / \mathrm{T}^{2}\right)$, b is Notch width $(\mathrm{L}), \mathrm{h}$ is head $(\mathrm{L})$, and $\mathrm{K}_{\mathrm{b}}$ and $\mathrm{K}_{\mathrm{h}}$ account for effects of viscosity and surface tension $(\mathrm{L})$.
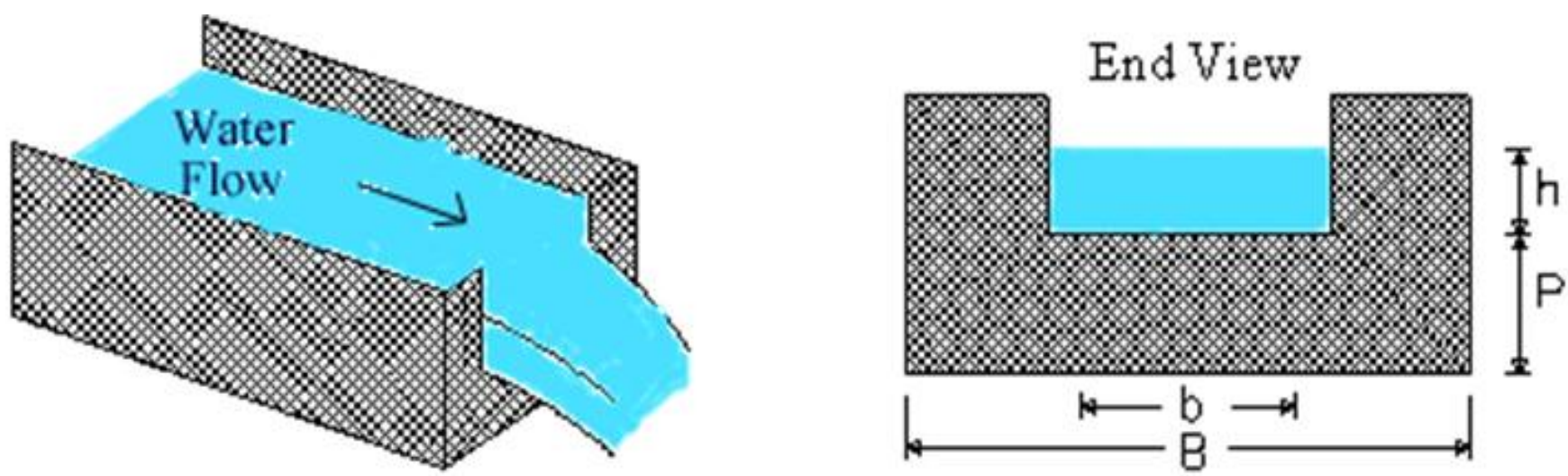

Figure-3. Rectangular weir for seepage measurement: installed rectangular weir for measuring the seepage at the downstream side the dam

Source: Michiele [17]

\subsection{Data Processing}

The rainfall coefficient method [20] was used to determine the monthly distribution of rainfall in the study area and then to distinguish between rainy months and dry months. This method involved the calculation of "rainfall coefficient" for each month at the station, the coefficient being the ratio between the mean monthly rainfall and one-twelfth of the annual mean (the latter referred to as "rainfall module").

In the catchment, pan evaporation data were not available. Because of this, the Penman method [21] was used to calculate the evaporation from the reservoir.

The Penman formula for open water evaporation is:

$$
E_{o}=\left(\frac{\Delta}{\partial}\right) H+\frac{E_{a}}{\left(\frac{\Delta}{\partial}+1\right)}
$$

Where $\mathrm{E}_{\mathrm{o}}$ is open water evaporation in $\mathrm{mm} / \mathrm{day} ; \mathrm{H}$ is the available heat; $\frac{\Delta}{\partial}$ is a weighting factor (a function of temperature); and, Ea is to be determined empirically in ( $\mathrm{mm} /$ day).

The formula requires values of $\mathrm{H}$ and $\mathrm{Ea}$ as well as $\frac{\Delta}{\partial}$ for its application in the open water evaporation from open water bodies such as the Gumselasa reservoir. 
$\mathrm{H}$ is calculated from incoming $\left(\mathrm{R}_{\mathrm{I}}\right)$ and outgoing $\left(\mathrm{R}_{\mathrm{o}}\right)$ radiation determined from sun shine records, temperature and relative humidity using

$$
H=R_{I}(1-r)-R_{o}
$$

Where $\mathrm{r}$ is the albedo and equals 0.05 for water.

Potential evapotranspiration of the catchment was determined by both Penman modified and Thornthwaite methods.

The Penman equation, which was later modified by MAFF [21] and called modified Penman equation, is given by:

$$
P E T=\frac{\left(\frac{\Delta}{\gamma}\right) H_{T}+E_{a t}}{\frac{\Delta}{\gamma}+1}
$$

Where:

PET is potential evapotranspiration $(\mathrm{mm} /$ day); $\Delta$ is slope of saturated vapor pressure Vs temperature curve $\left(\mathrm{mmHg} /{ }^{\circ} \mathrm{C}\right) ; \gamma$ is the hydrometric constant $\left(\mathrm{mmHg} /{ }^{\circ} \mathrm{C}\right)$;

$H_{T}=0.75 R_{I}(1-r)-R_{o}$;

$R_{I}(1-r)=0.75 R_{a} f_{a}\left(\frac{n}{N}\right)$

$\mathrm{R}_{\mathrm{I}}$ is incoming radiation;

$\mathrm{r}=0.25$ since the reflective coefficient for incident radiation, the albedo, from a short grassed surface is 0.25 ;

$f_{a}\left(\frac{n}{N}\right)=\left(0.16+0.62 \frac{n}{N}\right)$ for latitudes south of $54-2^{\circ} \mathrm{N}[22]$;

$R_{0}=\sigma T^{4}\left(0.47-0.075 \sqrt{e_{a}}\right)(0.17+0.83 n / N)$;

$\sigma \mathrm{T}^{4}$ is theoretical black body radiation at $\mathrm{T}$ (Mean air temperature in ${ }^{\mathrm{o}} \mathrm{C}$ );

$\mathrm{R}_{\mathrm{o}}$ is out going radiation;

$\sigma=$ Stefan-Boltzmann constant $\left(5.67^{*} 10^{-8} \mathrm{Wm}^{-2} \mathrm{~K}^{-4}\right)$;

$\mathrm{T}=$ Mean monthly temperature $\left({ }^{\mathrm{O}} \mathrm{C}\right)$;

$E_{a t}=0.35\left(1+\frac{u_{2}}{100}\right)\left(e_{s}-e_{a}\right) ;($ The extra subscript t signifies inclusion of transpiration effects $)$

$\mathrm{U}_{2}=$ wind speed at $2 \mathrm{~m}$ height $($ mile $/ \mathrm{hr})(1 \mathrm{mile}=1.609 \mathrm{~km})$;

$\mathrm{N}=$ Maximum possible sunshine hours (hr);

$\mathrm{n}=$ Sunshine hours $(\mathrm{hr})$;

$e_{s}=$ Saturated vapor pressure $(\mathrm{mm} \mathrm{Hg})$;

$e_{a}=$ Actual vapor pressure $(\mathrm{mm} \mathrm{Hg})$ is obtained from the formula:

$$
\mathrm{RH}=e_{s} / e_{a} * 100
$$

Where:

$\mathrm{RH}$ is relative humidity in percent.

$\mathrm{Ra}, \mathrm{N}, \sigma \mathrm{T}^{4}, e_{s}$ and $\Delta / \gamma$ were obtained from standard metrological tables, which can be readily found elsewhere in hydrology literature.

The Thornthwaite method [18] uses air temperature as an index of the energy available for evapotranspiration, assuming that air temperature is correlated with the integrated effects of net radiation and other controls of evapotranspiration and that the available energy is shared in fixed proportion between heating the atmosphere and evapotranspiration.

The Thornthwaite empirical equation is:

$$
P E T=N_{m} 16\left[\frac{10 T_{n}}{J}\right]^{a}
$$

Where, PET is potential evapotranspiration $(\mathrm{mm} / \mathrm{month}) ; \mathrm{T}_{\mathrm{n}}$ is mean monthly air temperature $\left({ }^{\circ} \mathrm{C}\right)$; $\mathrm{n}=1,2,3, \ldots \ldots \ldots, 12$ is the number of considered months; $\mathrm{J}$ is annual heat index and it is given by the equation;

$\mathrm{j}$ is monthly heat index and it is expressed as:

$$
\begin{aligned}
& J=\sum_{n=1}^{12} j \\
& \text { expressed as: }
\end{aligned}
$$

$$
j=\left(\frac{T_{n}}{5}\right)^{1.514}
$$

$$
\mathrm{a}=0.49239+0.01792 \mathrm{~J}-0.0000771 \mathrm{~J}^{2}+0.000000675 \mathrm{~J}^{3}
$$

$\mathrm{Nm}$ is daylight correction factor for potential evapotranspiration (latitude dependent).

Actual evapotranspiration data was not available in the stations employed in this study. Due to almost complete lack of field instruments such as lysimeters, the Thornthwaite water balance model [22] was used to estimate the actual evapotranspiration of the study area. The required parameters to determine actual evapotranspiration using this model are: mean monthly precipitation, mean monthly potential evapotranspiration, water holding capacity of the dominant soil type and monthly soil moisture storage.

The total mean actual evapotranspiration that occurs in the catchment was determined by arithmetic mean of the annual actual evapotranspiration from each area that is covered by specific soil type weighted by their area coverage.

Where

$$
A E T_{T}=\sum \frac{A E T_{i} a_{i}}{A}
$$


$\mathrm{AET}_{\mathrm{T}}$ is total actual evapotranspiration; $\mathrm{AET}_{\mathrm{i}}$ is mean annual actual evapotranspiration from each area that is covered by specific soil type; $\mathrm{a}_{\mathrm{i}}$ is area of each specific soil type; and, $\mathrm{A}$ is total catchment area.

The volume of runoff from the effective watershed area, water contributing areas, and command area were computed by using the runoff coefficient method [23] which employed the following formula.

$$
Q=K \cdot P \cdot A
$$

Where

$\mathrm{Q}$ is runoff, $\mathrm{m}^{3}: \mathrm{K}$ is a constant also called runoff coefficient depends up on the imperviousness of the drainage area: $\mathrm{P}$ is precipitation $(\mathrm{mm})$ : and, $\mathrm{A}$ is area of the basin $\left(\mathrm{m}^{2}\right)$.

The runoff coefficient $(K)$ in the runoff coefficient method was determined based on the land use, soil type (hydrological soil groups) and slope. The four hydrologic soil groups (HSGs) that described by Suresh [24] was used in the computation of runoff.

Water balance was done for the effective watershed area of the dam, for the dam, for the areas that contributing water for the command area and for the command area itself. The water balance of the effective watershed area of the dam, the dam, and the areas that contributing water for the command were conducted to quantify the different input of the hydrological parameters of the water balance to the command area.

Various assumptions have been made to derive the water balance equation for the studied area from the general equation, which is Eq. 1, and these are summarized below:

1. Since the computations are made on annual basis, net change of soil moisture and groundwater storage is assumed to be zero.

2. Subsurface water exchange with neighboring basins is assumed to be zero.

3. Assuming no artificial diversion from other basins.

Thus the water balance equation for the study area is written as follows, which is

$$
\mathrm{P}-\mathrm{ET}-\mathrm{Q}-\mathrm{I}=\mathrm{O} \quad(13)
$$

Where $\mathrm{P}=$ Precipitation; ET = Evapotranspiration; I = Infiltration; and, $\mathrm{Q}=$ Runoff from the catchment. In the case of the reservoir, evapotranspiration is replaced by evaporation.

\section{Results and Discussions}

\subsection{Hydrology}

The hydrology of the catchment has been examined in terms of land use, soil and climatic parameters of the catchment such as rainfall, temperature, wind speed, evapotranspiration and runoff. Detailed sections on climatic parameters follow.

\subsubsection{Rainfall}

\section{Mean Annual Rainfall}

A twenty years rainfall data (1992-2011) was collected for this study and the mean is tabulated and presented in Table 1. Accordingly, the mean annual rainfall of the study area is $485.89 \mathrm{~mm}$. The mean monthly rainfall averaged over the twenty years period of records for the Adigudem station is shown in Figure 4.

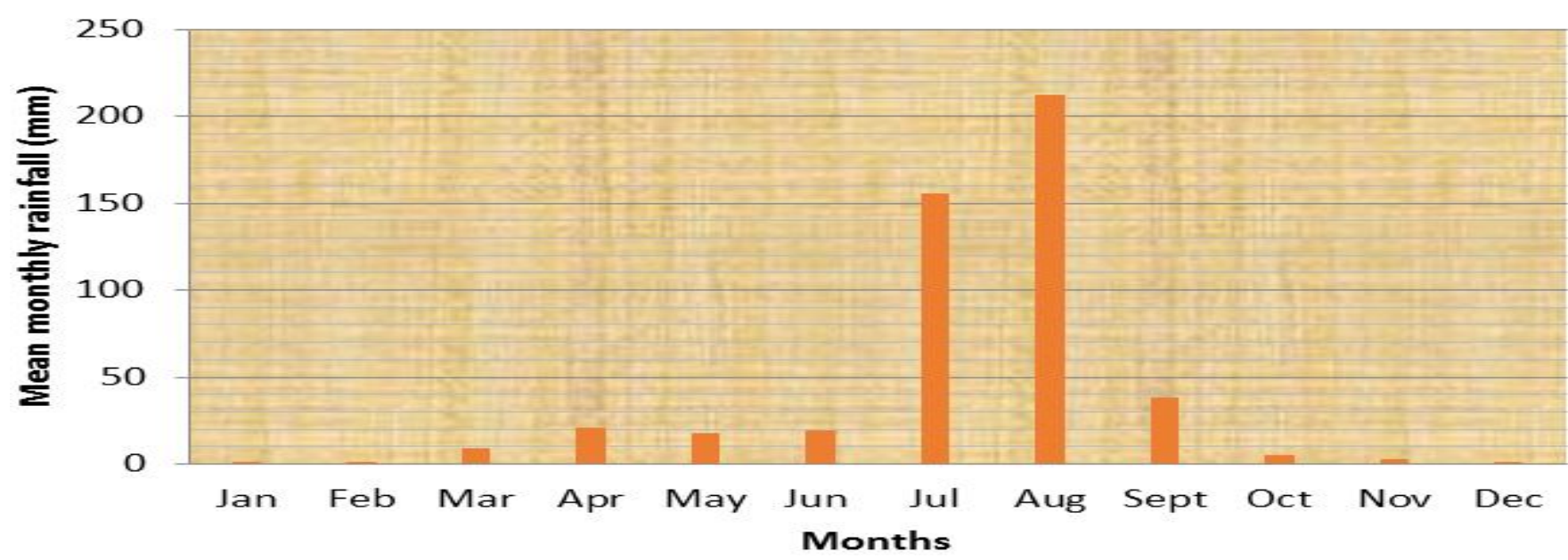

Figure-4. Mean monthly rainfall at Adigudem station. The rainfall is averaged over the twenty years (1992-2011) period of records at this station.

\begin{tabular}{|c|c|c|c|c|c|c|c|c|c|c|c|c|c|}
\hline Month & Jan & Feb & Mar & Apr & May & Jun & Jul & Aug & Sept & Oct & Nov & Dec & Mean annual \\
\hline MMRF & 1.25 & 1.25 & 9.20 & 21.03 & 18.11 & 19.65 & 155.46 & 212.1 & 38.50 & 5.01 & 3.05 & 1.30 & 485.89 \\
\hline
\end{tabular}

Table-1. Mean monthly rainfall at Adigudem station (in $\mathrm{mm}$ )

\section{Seasonality of Rainfall}

The seasonality of the study area was examined based on rainfall coefficient methods [20]. The guideline is given in Table 2 below. As depicted in Table 3, the catchment is characterized by one rainy season during the year, i.e., at this station rainy months are not separated into more than one group of rainy months by dry months. There are two dry seasons during the year. The rainy season in total have three months: July, August, and September.

The rains in September are small rain and accounts $7.92 \%$ of the average annual rainfall of the catchment. Big rains with a very high concentration occur in July and August, and these accounts for $75.64 \%$ of the average annual rainfall of the watershed.

The first dry season starts in January and ends in June. The second one starts in October and ends in December. The amount of rainfall that occurs during the nine months of dry seasons in total accounts for 
$16.43 \%$ of the average annual rainfall of the watershed. The study area has not experienced moderate and high concentration of rainfall, which is essential for direct recharge of groundwater.

Table-2. Rainfall coefficient values and their classification.

\begin{tabular}{l|l|l}
\hline S.N & Months & Rainfall coefficient values (RC) \\
\hline 1 & Dry month & Less than 0.6 \\
\hline 2 & Rainy & 0.6 and above \\
\hline 3 & Small rain & $0.6-0.9$ \\
\hline 4 & Big rain & 1 and above \\
\hline 4.1 & Moderate concentration & $1-1.9$ \\
\hline 4.2 & High concentration & $2-2.9$ \\
\hline 4.3 & Very High concentration & 3 and above \\
\hline
\end{tabular}

Table-3. Rainfall coefficient at the Adigudem station.

\begin{tabular}{l|l|l|l|l|l|l|l|l|l|l|l|l}
\hline Month & Jan & Feb & Mar & Apr & May & Jun & Jul & Aug & Sept & Oct & Nov & Dec \\
\hline MMRF & 1.25 & 1.25 & 9.20 & 21.03 & 18.11 & 19.65 & 155.46 & 212.08 & 38.50 & 5.01 & 3.05 & 1.30 \\
\hline RC & 0.03 & 0.03 & 0.23 & 0.52 & 0.46 & 0.48 & 3.84 & 5.25 & 0.95 & 0.12 & 0.07 & 0.03 \\
\hline Season & Dry & Dry & Dry & Dry & Dry & Dry & Rainy & Rainy & Rainy & Dry & Dry & Dry \\
\hline Amount & & & & & & & Big & Big & Small & & & \\
\hline Concentration & - & - & - & - & - & - & $\begin{array}{l}\text { Very } \\
\text { high }\end{array}$ & $\begin{array}{l}\text { Very } \\
\text { high }\end{array}$ & - & - & - & - \\
\hline
\end{tabular}

Where, MMRF is mean monthly rainfall $(\mathrm{mm})$; and, $\mathrm{RC}$ is rainfall coefficient values.

\subsubsection{Temperature}

For temperature analysis of the area, a twenty-year (1992-2011) maximum temperature and minimum temperature data were taken and analyzed. The mean annual minimum temperature of the study area is 11.73 ${ }^{\circ} \mathrm{C}$ and the mean annual maximum temperature is $24.21{ }^{\circ} \mathrm{C}$. The mean annual air temperature of the area is $17.97{ }^{\circ} \mathrm{C}$ (Table 4). The mean monthly maximum and minimum temperature are observed in June and December, which are $27.01^{\circ} \mathrm{C}$ and $9.39^{\circ} \mathrm{C}$, respectively.

As it is shown in the above Table 4 , the minimum air temperature is $15.94{ }^{\circ} \mathrm{C}$ in December and the maximum air temperature is $20.39^{\circ} \mathrm{C}$ in May. The annual range of temperature is $4.45{ }^{\circ} \mathrm{C}$.

Table-4. Mean monthly temperature at Mekelle Airport meteorological station.

\begin{tabular}{l|l|l|l|l|l|l|l|l|l|l|l|l|l}
\hline Month & Jan & Feb & Mar & Apr & May & Jun & Jul & Aug & Sep & Oct & Nov & Dec & MA \\
\hline MMMxT $\left({ }^{\circ} \mathrm{C}\right)$ & 22.97 & 24.39 & 25.13 & 25.79 & 26.94 & 27.01 & 23.31 & 22.36 & 24.25 & 23.62 & 22.45 & 22.26 & \\
\hline MMMnT $\left({ }^{\circ} \mathrm{C}\right)$ & 9.39 & 10.38 & 11.86 & 13.29 & 13.85 & 13.53 & 13.21 & 13.05 & 11.19 & 11.06 & 10.35 & 9.62 & \\
\hline MMT $\left({ }^{\circ} \mathrm{C}\right)$ & 16.18 & 17.39 & 18.49 & 19.54 & 20.39 & 20.27 & 18.26 & 17.71 & 17.72 & 17.34 & 16.40 & 15.94 & 17.97 \\
\hline
\end{tabular}

Where MMMxT is Mean monthly maximum temperature; MMMnT is Mean monthly minimum temperature; MMT is Mean monthly air

temperature; and, MA is mean annual air temperature.

\subsubsection{Wind Speed}

For the wind speed analysis of the area, eleven years (1995 to 2011) data records were used. The mean monthly values were computed and are given in the Table 5 below. The maximum and minimum wind speed value is obtained in February $(4.23 \mathrm{~m} / \mathrm{s})$ and in August $(1.71 \mathrm{~m} / \mathrm{s})$, respectively. In general, the highest and lowest wind speed values are found in the dry and rainy month, respectively.

\subsubsection{Sunshine Hours}

For the analysis of solar radiation of the area, the data that was recorded from 1991 to 2011 were utilized. The mean monthly sunshine hours of the area are given in Table 5 below. The maximum sunshine hour is recorded in December (9.87 hours) whereas the minimum one is in August (5.12 hours). Generally, the maximum sunshine hours are found in dry months whereas the minimum are in very highly rainy months.

\subsubsection{Humidity}

For this analysis, the data that was recorded from 1991 to 2011 were utilized. The mean monthly values were computed and are given in the Table 5 below. The maximum and minimum relative humidity values are found in August $(74.23 \%)$ and May (37.55 \%), respectively. In general, the highest humidity values are found in the rainy months whereas the lowest values are in dry months.

\begin{tabular}{|c|c|c|c|c|c|c|c|c|c|c|c|c|}
\hline Months & Jan & Feb & Mar & Apr & May & Jun & Jul & Aug & Sep & Oct & Nov & Dec \\
\hline RH (\%) & 46.47 & 41.09 & 40.85 & 40.71 & 37.55 & 40.20 & 69 & 74.23 & 50.55 & 43.15 & 45.05 & 44.25 \\
\hline $\mathrm{n}(\mathrm{hr} / \mathrm{d})$ & 9.60 & 9.74 & 9.03 & 8.94 & 9.62 & 7.44 & 5.13 & 5.12 & 7.70 & 9.49 & 9.85 & 9.87 \\
\hline $\mathrm{U}(\mathrm{m} / \mathrm{S})$ & 3.46 & 4.23 & 4.13 & 4 & 2.95 & 2.14 & 1.9 & 1.71 & 1.78 & 3.06 & 3.64 & 3.76 \\
\hline
\end{tabular}

Where $\mathrm{RH}=$ relative humidity in percentage (\%); $\mathrm{n}=$ Sun shine hours per day; and, $\mathrm{U}=$ Wind speed in meter per second.

\subsubsection{Evaporation from the Reservoir}

The monthly water loss from Gumselassa reservoir due to evaporation was calculated by using the Penman formula, Eq. (3). The result shows that the total annual water loss by evaporation is $1263.27 \mathrm{~mm}$ or 0.505 million cubic meters (Table 6). The highest value of evaporation was in month May in which the temperature is also high. The table below shows the total mean annual evaporation loss calculated using Penman formula. 
Table-6. Evaporation from Gumselassa dam reservoir.

\begin{tabular}{l|l|l|l|l|l|l|l|l|l|l|l|l|l}
\hline Month & Jan & Feb & Mar & Apr & May & Jun & Jul & Aug & Sep & Oct & Nov & Dec & Annual \\
\hline $\mathrm{H}$ & 3.64 & 4.35 & 4.83 & 5.2 & 5.36 & 4.57 & 4.12 & 4.24 & 4.66 & 4.53 & 3.88 & 4.43 & \\
\hline $\mathrm{Ea}$ & 1.38 & 1.65 & 1.77 & 1.89 & 2.10 & 1.99 & 0.89 & 0.71 & 1.37 & 1.55 & 1.44 & 1.44 & \\
\hline $\mathrm{E}$ & 2.83 & 3.42 & 3.82 & 4.15 & 4.78 & 3.78 & 3.05 & 3.05 & 3.55 & 3.51 & 3.02 & 2.72 & \\
\hline $\mathrm{E}_{\mathrm{o}}$ & 87.73 & 95.76 & 118.42 & 124.5 & 143.4 & 117.18 & 91.5 & 94.55 & 106.5 & 108.81 & 90.6 & 84.32 & $1,263.27$ \\
\hline
\end{tabular}

Where $\mathrm{E}$ is evaporation in $\mathrm{mm} /$ day, and $\mathrm{E}_{\mathrm{o}}$ is evaporation in $\mathrm{mm} / \mathrm{month}$.

\subsubsection{Evapotranspiration}

In this study, an attempt was made to estimate both potential evapotranspiration and actual evapotranspiration for the catchment.

\section{Potential Evapotranspiration}

Both Penman combination and Thornthwaite methods were used to compute the potential evapotranspiration of the Gumselassa catchment.

According to Thornthwaite method, the computed mean annual potential evapotranspiration is $805.83 \mathrm{~mm}$ (Table 7). Using Penman method the potential evapotranspiration for the catchment was computed and the result is given in the Table 8. Accordingly, the mean annual potential evapotranspiration for the Gumselassa catchment is $1,144.29 \mathrm{~mm}$. Preference to the value determined by Penman method is given due to the number of parameters that are involved in the computation of the potential evapotranspiration.

Table-7. Potential evapotranspiration using Thornthwaite method.

\begin{tabular}{l|l|l|l|l|l|l|l|l|l|l|l|l|l}
\hline Month & Jan & Feb & Mar & Apr & May & Jun & Jul & Aug & Sep & Oct & Nov & Dec & Annual \\
\hline MMT $\left({ }^{\circ} \mathrm{C}\right)$ & 16.18 & 17.39 & 18.49 & 19.54 & 20.39 & 20.27 & 18.26 & 17.71 & 17.72 & 17.34 & 16.4 & 15.94 & 17.97 \\
\hline $\mathrm{I}_{\mathrm{m}}$ & 5.92 & 6.60 & 7.24 & 7.87 & 8.39 & 8.32 & 7.11 & 6.79 & 6.79 & 6.57 & 6.04 & 5.79 & $\mathrm{I}=83.34$ \\
\hline $\mathrm{N}_{\mathrm{m}}$ & 0.94 & 0.97 & 1 & 1.04 & 1.06 & 1.08 & 1.07 & 1.05 & 1.07 & 0.98 & 0.95 & 0.93 & \\
\hline PET & 50.88 & 59.95 & 69.19 & 79.66 & 87.81 & 88.49 & 72.35 & 67.11 & 68.46 & 60.25 & 52.71 & 48.97 & 805.83 \\
\hline
\end{tabular}

Where MMT is Mean monthly air temperature; $\mathrm{I}_{\mathrm{m}}$ is Monthly heat index; $\mathrm{N}_{\mathrm{m}}$ is Latitudinal correction factor for $10^{\circ} \mathrm{N}$; and, PET is Corrected potential Evapotranspiration in (mm).

Table-8. Potential evapotranspiration using Penman method.

\begin{tabular}{l|l|l|l|l|l|l|l|l|l|l|l|l|l}
\hline Month & Jan & Feb & Mar & Apr & May & Jun & Jul & Aug & Sep & Oct & Nov & Dec & Mean annual \\
\hline $\mathrm{T}\left(\mathrm{C}^{\mathrm{O}}\right)$ & 16.18 & 17.39 & 18.49 & 19.54 & 20.39 & 20.27 & 18.26 & 17.71 & 17.72 & 17.34 & 16.40 & 15.94 & \\
\hline $\mathrm{RH}(\%)$ & 46.47 & 41.09 & 40.85 & 40.71 & 37.55 & 40.19 & 69.00 & 74.2 & 50.55 & 43.15 & 45.05 & 44.25 & \\
\hline $\mathrm{Es}(\mathrm{mmHg})$ & 13.73 & 14.73 & 15.81 & 16.95 & 18.16 & 18.16 & 15.81 & 15.27 & 15.27 & 14.73 & 13.98 & 13.73 & \\
\hline $\mathrm{E}_{\mathrm{a}}(\mathrm{mmHg})$ & 6.38 & 6.05 & 6.48 & 6.90 & 6.82 & 7.27 & 10.91 & 11.33 & 7.72 & 6.36 & 6.29 & 6.08 & \\
\hline $\mathrm{U}(\mathrm{M} / \mathrm{S})$ & 3.46 & 4.23 & 4.13 & 4 & 2.95 & 2.14 & 1.9 & 1.71 & 1.78 & 3.06 & 3.64 & 3.76 & \\
\hline $\mathrm{n}(\mathrm{hr} / \mathrm{d})$ & 9.6 & 9.74 & 9.03 & 8.94 & 9.62 & 7.44 & 5.13 & 5.12 & 7.7 & 9.49 & 9.85 & 9.87 & \\
\hline $\mathrm{N}(\mathrm{hr} / \mathrm{d})$ & 11.3 & 11.6 & 12.00 & 12.50 & 12.80 & 13.00 & 12.90 & 12.60 & 12.20 & 11.80 & 11.40 & 11.20 & \\
\hline $\mathrm{n} / \mathrm{N}$ & 0.85 & 0.84 & 0.75 & 0.72 & 0.75 & 0.57 & 0.39 & 0.41 & 0.63 & 0.80 & 0.86 & 0.88 & \\
\hline $\mathrm{F}_{\mathrm{a}}(\mathrm{n} / \mathrm{N})$ & 0.69 & 0.68 & 0.63 & 0.61 & 0.63 & 0.51 & 0.40 & 0.41 & 0.55 & 0.66 & 0.69 & 0.71 & \\
\hline $\mathrm{Ra}(\mathrm{MM} / \mathrm{d})$ & 11.80 & 13.15 & 14.4 & 15.20 & 15.35 & 15.30 & 15.30 & 15.20 & 14.60 & 13.55 & 12.20 & 11.45 & \\
\hline$\sigma \mathrm{T}_{\mathrm{a}}(\mathrm{min})$ & 14.1 & 14.3 & 14.5 & 14.7 & 14.9 & 14.9 & 14.5 & 14.4 & 14.4 & 14.3 & 14.2 & 14.1 & \\
\hline $\mathrm{R}_{\mathrm{o}}(\mathrm{mm} / \mathrm{d})$ & 3.46 & 3.54 & 3.21 & 3.08 & 3.24 & 2.57 & 1.59 & 1.59 & 2.61 & 3.35 & 3.54 & 3.62 & \\
\hline$\Delta$ & 1.80 & 1.91 & 2.03 & 2.16 & 2.32 & 2.27 & 2.03 & 1.97 & 1.97 & 1.91 & 1.83 & 1.80 & \\
\hline $\bar{\partial}$ & & & & & & & & & & & & \\
\hline $\mathrm{R}_{\mathrm{i}}(1-\mathrm{r})$ & 6.08 & 6.71 & 6.75 & 6.91 & 7.19 & 5.89 & 4.61 & 4.72 & 6.03 & 6.66 & 6.34 & 6.06 & \\
\hline $\mathrm{H}_{\mathrm{T}}(\mathrm{mm} / \mathrm{d})$ & 2.62 & 3.71 & 3.54 & 3.83 & 3.95 & 3.32 & 3.02 & 3.13 & 3.42 & 3.31 & 2.80 & 2.44 & \\
\hline $\mathrm{E}_{\mathrm{at}}(\mathrm{mm} / \mathrm{d})$ & 2.66 & 3.17 & 3.14 & 3.66 & 4.09 & 3.89 & 1.75 & 1.40 & 2.69 & 3.02 & 2.79 & 2.78 & \\
\hline $\mathrm{PET}(\mathrm{mm} / \mathrm{d})$ & 2.63 & 3.52 & 3.49 & 3.78 & 3.99 & 3.49 & 2.60 & 2.55 & 3.17 & 3.21 & 2.79 & 2.56 & \\
\hline $\mathrm{PET}(\mathrm{mm} / \mathrm{M})$ & 81.53 & 98.56 & 108.19 & 113.4 & 119.7 & 108.19 & 78 & 79.05 & 95.1 & 99.51 & 83.7 & 79.36 & $1,144.29$ \\
\hline
\end{tabular}

\section{Actual Evapotranspiration}

Actual evapotranspiration was estimated for the dominant soil types and the respective root depth for the effective watershed, water contributing areas to the command area, and the command area of the study area, respectively. For the effective watershed, water contributing areas and the command area, these results are summarized and are given in Tables $10-14$ below.

For computation of the actual evapotranspiration the soil result of the areas for field capacity, permanent welting point, root depth and available water capacity are given in Table 9 below.

Table-9. Result of soils for field capacity, permanent welting point (PWP) and available water capacity (AWC).

\begin{tabular}{l|l|l|l|l}
\hline Location & Field Capacity $(\mathbf{g m} / \mathbf{g m})$ or $\%$ & $\mathbf{P W P}(\mathbf{g m} / \mathbf{g m})$ or $\%$ & Root Depth $(\mathbf{m})$ & AWC \\
\hline WCA - & 32.20 & 21.62 & 0.75 & 79.31 \\
\hline UCA2 & 32.88 & 23.76 & 0.8 & 72.98 \\
\hline LCA3 & 29.13 & 19.12 & 0.5 & 50.02 \\
\hline EWS4 & 19.71 & 11.14 & 0.6 & 51.37 \\
\hline EWS5 & 21.86 & 13.18 & 0.7 & 60.77 \\
\hline EWS6 & 29.41 & 20.49 & 0.6 & 53.54 \\
\hline WCA - 2 & 25.13 & 8.83 & 0.6 & 97.80 \\
\hline Where WCA $=$ water contributing area; EWS = effective watershed; UCA = upper command area; and, LCA = lower command area.
\end{tabular}


Table-10. Average monthly water balance of Gumselassa command area for a soil with an average available water capacity of $61.5 \mathrm{~mm}$. The soil is clay with an

\begin{tabular}{l|l|l|l|l|l|l|l|l|l|l|l|l|l}
\multicolumn{1}{l}{ average root depth of $0.65 \mathrm{~m}$. All the values are in mm. } \\
\hline Month & Jan & Feb & Mar & Apr & May & Jun & Jul & Aug & Sep & Oct & Nov & Dec & Annual \\
\hline P & 1.25 & 1.25 & 9.2 & 21.03 & 18.11 & 19.65 & 155.46 & 212.08 & 38.5 & 5.01 & 3.05 & 1.3 & 485.89 \\
\hline PET & 50.88 & 59.95 & 69.19 & 79.66 & 87.81 & 88.49 & 72.35 & 67.11 & 68.46 & 60.25 & 52.71 & 48.97 & 805.83 \\
\hline P-PET & -49.63 & -58.7 & -59.99 & -58.63 & -69.7 & -68.84 & 83.11 & 114.97 & -29.96 & -55.24 & -49.66 & -47.67 & \\
\hline APWL & -232.16 & -290.9 & -350.85 & -409.48 & -479.18 & -548.02 & & & -29.96 & -85.2 & -134.9 & -182.53 & \\
\hline SM & 1.22 & 0.45 & 0.17 & 0.06 & 0.02 & 0.006 & 61.50 & 61.50 & 37.10 & 14.61 & 6.32 & 2.83 & \\
\hline$\Delta$ SM & -1.60 & -0.77 & -0.29 & -0.10 & -0.04 & -0.01 & 61.49 & 0 & -24.4 & -22.49 & -8.29 & -3.49 & \\
\hline AET & 2.85 & 2.01 & 9.49 & 21.13 & 18.15 & 19.66 & 72.35 & 67.11 & 62.90 & 27.5 & 11.34 & 4.79 & 319.3 \\
\hline
\end{tabular}

Table-11. Average monthly water balance of Gumselassa effective watershed area for a soil with available water capacity of $56.07 \mathrm{~mm}$. The soil is clay with

\begin{tabular}{l|l|l|l|l|l|l|l|l|l|l|l|l|l}
\multicolumn{1}{c}{ Month } & Jan & Feb & Mar & \multicolumn{1}{c|}{ Apr } & May & Jun & Jul & Aug & Sep & Oct & Nov & Dec & Annual \\
\hline P & 1.25 & 1.25 & 9.2 & 21.03 & 18.11 & 19.65 & 155.46 & 212.08 & 38.5 & 5.01 & 3.05 & 1.3 & 485.89 \\
\hline PET & 50.88 & 59.95 & 69.19 & 79.66 & 87.81 & 88.49 & 72.35 & 67.11 & 68.46 & 60.25 & 52.71 & 48.97 & 805.83 \\
\hline P-PET & -49.63 & -58.7 & -59.99 & -58.63 & -69.7 & -68.84 & 83.11 & 114.97 & -29.96 & -55.24 & -49.66 & -47.67 & \\
\hline APWL & -232.16 & -290.9 & -350.85 & -409.48 & -479.18 & -548.02 & & & -29.96 & -85.2 & -134.9 & -182.53 & \\
\hline SM & 0.52 & 0.16 & 0.05 & 0.02 & 0.004 & 0.001 & 52.46 & 52.46 & 28.90 & 9.63 & 3.58 & 1.39 & \\
\hline$\Delta$ SM & -0.871 & -0.356 & -0.112 & -0.033 & -0.011 & -0.003 & 52.456 & 0 & -23.56 & -19.272 & -6.044 & -2.197 & \\
\hline AET & 2.12 & 1.61 & 9.31 & 21.06 & 18.12 & 19.65 & 72.35 & 67.11 & 62.06 & 24.28 & 9.09 & 3.50 & 310.27 \\
\hline
\end{tabular}

Table-12. Average monthly water balance of Gumselassa effective watershed area for a soil with an available water capacity of $53.54 \mathrm{~mm}$. The soil is sandy clay loam with an average root depth of $0.6 \mathrm{~m}$. All

\begin{tabular}{|c|c|c|c|c|c|c|c|c|c|c|c|c|c|}
\hline Month & Jan & Feb & Mar & Apr & May & Jun & Jul & Aug & Sep & Oct & Nov & Dec & Annual \\
\hline $\bar{P}$ & 1.25 & 1.25 & 9.2 & 21.03 & 18.11 & 19.65 & 155.46 & 212.08 & 38.5 & 5.01 & 3.05 & 1.3 & 485.89 \\
\hline PET & 50.88 & 59.95 & 69.19 & 79.66 & 87.81 & 88.49 & 72.35 & 67.11 & 68.46 & 60.25 & 52.71 & 48.97 & 805.83 \\
\hline P-PET & -49.63 & -58.7 & -59.99 & -58.63 & -69.7 & -68.84 & 83.11 & 114.97 & -29.96 & -55.24 & -49.66 & -47.67 & \\
\hline APWL & -232.16 & -290.9 & -350.85 & -409.48 & -479.18 & -548.02 & & & -29.96 & -85.2 & -134.9 & -182.53 & \\
\hline SM & 1.15 & 0.42 & 0.15 & 0.056 & 0.02 & 0.01 & 60.77 & 60.77 & 36.42 & 14.18 & 6.07 & 2.69 & \\
\hline$\Delta \mathrm{SM}$ & -1.54 & -0.73 & -0.27 & -0.1 & -0.04 & -0.01 & 60.76 & 0 & -24.34 & -22.25 & -8.11 & -3.38 & \\
\hline $\mathrm{AET}$ & 2.79 & 1.98 & 9.47 & 21.13 & 18.15 & 19.66 & 72.35 & 67.11 & 62.84 & 27.26 & 11.16 & 4.68 & 318.57 \\
\hline
\end{tabular}


Table-13. Average monthly water balance at Gumselassa water contributing area - 1 for a soil with available water capacity of $79.31 \mathrm{~mm}$. The soil is clay with an average root depth of $0.75 \mathrm{~m}$. All the

\begin{tabular}{|c|c|c|c|c|c|c|c|c|c|c|c|c|c|}
\hline Month & Jan & Feb & Mar & Apr & May & Jun & Jul & Aug & Sep & Oct & Nov & Dec & Annual \\
\hline $\mathrm{P}$ & 1.25 & 1.25 & 9.2 & 21.03 & 18.11 & 19.65 & 155.46 & 212.08 & 38.5 & 5.01 & 3.05 & 1.3 & 485.89 \\
\hline PET & 50.88 & 59.95 & 69.19 & 79.66 & 87.81 & 88.49 & 72.35 & 67.11 & 68.46 & 60.25 & 52.71 & 48.97 & 805.83 \\
\hline P-PET & -49.63 & -58.7 & -59.99 & -58.63 & -69.7 & -68.84 & 83.11 & 114.97 & -29.96 & -55.24 & -49.66 & -47.67 & \\
\hline APWL & -232.16 & -290.9 & -350.85 & -409.48 & -479.18 & -548.02 & & & -29.96 & -85.2 & -134.9 & -182.53 & \\
\hline SM & 3.91 & 1.83 & 0.84 & 0.39 & 0.16 & 0.07 & 79.31 & 79.31 & 53.79 & 26.29 & 13.81 & 7.44 & \\
\hline$\Delta \mathrm{SM}$ & -3.53 & -2.09 & -0.99 & -0.45 & -0.23 & -0.09 & 79.24 & 0 & -25.52 & -27.5 & -12.48 & -6.37 & \\
\hline AET & 4.78 & 3.34 & 10.19 & 21.48 & 18.34 & 19.74 & 72.35 & 67.11 & $\begin{array}{l}64.02 \\
\end{array}$ & 32.51 & 15.52 & 7.67 & 337.06 \\
\hline
\end{tabular}

Table-14. Average monthly water balance at Gumselassa water contributing area - 2 for a soil with available water capacity of $97.8 \mathrm{~mm}$. The soil is clay with an average root depth of 0.6

\begin{tabular}{c|c|c|c|c|c|c|c|c|c|c|c|c|c}
\multicolumn{1}{l}{. All the values are $\mathrm{in} m$. } \\
\hline Month & Jan & Feb & Mar & Apr & May & Jun & Jul & Aug & Sep & Oct & Nov & Dec & Annual \\
\hline P & 1.25 & 1.25 & 9.2 & 21.03 & 18.11 & 19.65 & 155.46 & 212.08 & 38.5 & 5.01 & 3.05 & 1.3 & 485.89 \\
\hline PET & 50.88 & 59.95 & 69.19 & 79.66 & 87.81 & 88.49 & 72.35 & 67.11 & 68.46 & 60.25 & 52.71 & 48.97 & 805.83 \\
\hline P-PET & -49.63 & -58.7 & -59.99 & -58.63 & -69.7 & -68.84 & 83.11 & 114.97 & -29.96 & -55.24 & -49.66 & -47.67 & \\
\hline APWL & -232.16 & -290.9 & -350.85 & -409.48 & -479.18 & -548.02 & & & -29.96 & -85.2 & -134.9 & -182.53 & \\
\hline SM & 8.69 & 4.71 & 2.52 & 1.36 & 0.66 & 0.32 & 97.80 & 97.80 & 71.56 & 40.23 & 23.97 & 14.58 & \\
\hline$\Delta$ SM & -5.89 & -3.98 & -2.19 & -1.15 & -0.71 & -0.34 & 97.48 & 0 & -26.24 & -31.33 & -16.26 & -9.39 & \\
\hline AET & 7.14 & 5.23 & 11.39 & 22.18 & 18.82 & 19.99 & 72.35 & 67.11 & 64.74 & 36.34 & 19.31 & 10.69 & 355.29 \\
\hline
\end{tabular}

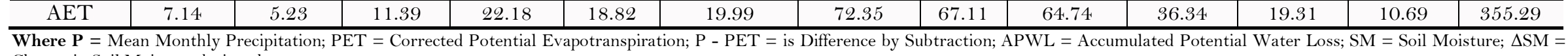

Change in Soil Moisture during the

apotranspiration. 
The summery result of actual evapotranspiration (Table 15) shows the maximum is in the southern water contributing area to the command area which has clay soil.

\begin{tabular}{l|l}
\multicolumn{2}{c}{ Table-15. Summary of the computed values of actual evapotranspiration. } \\
\hline Area & Actual Evapotranspiration (mm) \\
\hline Effective watershed with sandy clay loam soil (EWSSCL) & 318.57 \\
\hline Effective watershed with clay soil (EWSC) & 310.27 \\
\hline Water contributing area - 1 (WCA - 1) & 337.06 \\
\hline Command area (CA) & 319.3 \\
\hline Water contributing area - 2 (WCA - 2) & 355.29 \\
\hline
\end{tabular}

\subsubsection{Surface Runoff}

In this study, the mean annual runoff for the effective watershed area (upper catchment area), water contributing areas and the command area was determined using runoff coefficient method, Eq. (12). The computation of runoff was done by classifying the catchment into different land use, slope class and the hydrologic soil groups, and the result is summarized and given in Table 16 below.

Table-16. Surface runoff from the different parts of the catchment.

\begin{tabular}{l|l|l|l|l|l|l|l}
\hline Catchments & Land use type & Soil type & $\begin{array}{l}\text { Hydrologic } \\
\text { group of soil }\end{array}$ & Slope & $\begin{array}{l}\text { Runoff } \\
\text { coefficient }\end{array}$ & Area $\left(\mathbf{k m}^{2}\right)$ & $\mathbf{R u n o f f}_{\left(\mathbf{m}^{3}\right)}$ \\
\hline EWSSCL & Cultivated land & $\begin{array}{l}\text { Fine sandy } \\
\text { clay loam }\end{array}$ & C & $0-2$ & 0.14 & 17.16 & $1.167 \mathrm{X} 10^{6}$ \\
\hline EWSC & Cultivated land & Clay & $\mathrm{D}$ & $0-2$ & 0.18 & 4.98 & $0.44 \mathrm{X} 10^{6}$ \\
\hline CA & Cultivated land & Clay & $\mathrm{D}$ & $0-2$ & 0.18 & 1 & $8.75 \mathrm{X} 10^{4}$ \\
\hline WCA - 2 & Cultivated land & Clay & $\mathrm{D}$ & $0-2$ & 0.18 & 3.99 & $3.49 \mathrm{X} 10^{5}$ \\
\hline WCA - 1 & Cultivated land & Clay & $\mathrm{D}$ & $0-2$ & 0.18 & 0.55 & $0.048 \mathrm{X} 10^{6}$ \\
\hline
\end{tabular}

\subsection{Water Balance}

\section{Water Balance for the Effective Watershed with Sandy Loam Soil}

Precipitation is the only input component to the effective watershed area with sandy clay loam soil, whereas actual evapotranspiration, runoff and infiltration are on the output side.

From the budget equation, the amount of water that percolates into the ground in the upper catchment as a groundwater accretion has been calculated as follows.

$\mathrm{A}_{\mathrm{s}}=$ Area of the upper catchment $=17.16$ sq. $\mathrm{km} ; \mathrm{AET}=54.683^{*} 10^{5} \mathrm{~m}^{3} ; \mathrm{P}=83.4^{*} 10^{5} \mathrm{~m}^{3} ;$ and, $\mathrm{Q}=11.67^{*} 10^{5} \mathrm{~m}^{3}$. From Equation 13,

$\mathrm{I}=\mathrm{P}-\mathrm{AET}-\mathrm{Q}=1.705^{*} 10^{6} \mathrm{~m}^{3}$

\section{Water Balance for Effective Watershed with Clay Soil}

Precipitation is the only input component to the effective watershed area with clay soil, whereas actual evapotranspiration, runoff and infiltration are on the outputs from the area.

From the budget equation, Eq. 13, the amount of water that percolates into the ground in the upper catchment as a groundwater accretion has been calculated as follows.

$\mathrm{A}_{\mathrm{s}}=$ Area of the upper catchment $=4.98 \mathrm{sq} . \mathrm{km}$; AET $=1.55^{*} 10^{6} \mathrm{~m}^{3} ; \mathrm{P}=2.42^{*} 10^{6} \mathrm{~m}^{3} ;$ and, $\mathrm{Q}=0.44^{*} 10^{6} \mathrm{~m}^{3}$.

Using Equation 13

$\mathrm{I}=\mathrm{P}-\mathrm{AET}-\mathrm{Q}=0.43^{*} 10^{6} \mathrm{~m}^{3}$

\section{Water Balance for the Reservoir}

Precipitation and runoff from effective watershed with sandy loam and clay soil are the input components to the reservoir whereas evaporation, infiltration at the reservoir site or bed, and the discharges to the command area constitute the output components.

From the budget equation, the amount of water that percolates into the ground at the reservoir site as a groundwater accretion has been calculated as follows.

$\mathrm{A}_{\mathrm{s}}=$ Area of the reservoir $=0.4 \mathrm{sq} . \mathrm{km} ; \mathrm{E}=$ Evaporation from the reservoir $=0.505 \times 10^{6} \mathrm{~m}^{3} ; \mathrm{P}=0.194 \times 10^{6} \mathrm{~m}^{3} ;$ $\mathrm{Qi}=1.607^{*} 10^{6} \mathrm{~m}^{3}$; (sum of input discharges from effective watershed with clay and sandy loam); $\mathrm{Q}_{\mathrm{d}}=0.203 \mathrm{x}^{6} \mathrm{~m}^{3}$. (Discharge from the reservoir to the command area, which is measured at the field); and, Qs $=0.35 \times 10^{6} \mathrm{~m}^{3}$; (Seepage Discharge)

$\mathrm{I}=\mathrm{P}+\mathrm{Qi}-\mathrm{E}-\mathrm{Qd}-\mathrm{Qs}$

$\mathrm{I}=[(0.194+1.607-0.505-0.203-0.35)] \times 10^{6} \mathrm{~m}^{3}=0.743 \times 10^{6} \mathrm{~m}^{3}$

\section{Water Balance for Water Contributing Area - 1}

In the water contributing area - 1 to the command area the only input is precipitation and the output hydrologic components from the area are actual evapotranspiration, runoff and infiltration.

Therefore, from the budget equation, the amount of water that percolates into the ground at the northern water contributing area as a groundwater accretion has been calculated as follows.

$\mathrm{A}_{\mathrm{s}}=0.55 \mathrm{sq} . \mathrm{km} ; \mathrm{AET}=0.19 \times 10^{6} \mathrm{~m}^{3} ; \mathrm{P}=0.267 \times 10^{6} \mathrm{~m}^{3}$; and, $\mathrm{Q}=0.048 \times 10^{6} \mathrm{~m}^{3}$.

Using Equation 13

$\mathrm{I}=\mathrm{P}-\mathrm{ET}-\mathrm{Q}=0.029 \times 10^{6} \mathrm{~m}^{3}$ 


\section{Water Balance for Water Contributing Area-2}

The only input for water contributing area - 2 for the command area is precipitation, and actual evapotranspiration, runoff and infiltration are the outputs from the area.

Therefore, from the budget equation, the amount of water that percolates into the ground at the southern water contributing area as a groundwater accretion has calculated as follows.

$\mathrm{A}_{\mathrm{s}}=3.99 \mathrm{sq} . \mathrm{km} ; \mathrm{AET}=1.42 \times 10^{6} \mathrm{~m}^{3} ; \mathrm{P}=1.94 \times 10^{6} \mathrm{~m}^{3} ;$ and, $\mathrm{Q}=0.349 \times 10^{6} \mathrm{~m}^{3}$.

Using Equation 13

$\mathrm{I}=\mathrm{P}-\mathrm{ET}-\mathrm{Q}=0.171^{*} 10^{6} \mathrm{~m}^{3}$

\section{Water Balance for the Command Area}

Precipitation, the discharge from the reservoir, seepage and the surface runoff from the water contributing areas are the input components to the command area whereas evapotranspiration, runoff from the command area, discharge to water supply and infiltration into the groundwater at the command area constitutes the output components.

From the budget equation, the amount of water that percolates into the ground in the command area as a groundwater accretion has calculated as follows.

$\mathrm{A}_{\mathrm{s}}=$ Area of the command area $=1 \mathrm{sq} . \mathrm{km} ;$ AET $=0.32 \times 10^{6} \mathrm{~m}^{3} ; \mathrm{P}=0.486 \times 10^{6} \mathrm{~m}^{3} ; \mathrm{Qs}=0.35 \times 10^{6} \mathrm{~m}^{3} ;$ (Seepage Discharge); $\mathrm{Q}_{\mathrm{d}}=0.203 \times 10^{6} \mathrm{~m}^{3}$ (Discharge from the reservoir to the command area, which is measured at the field); $Q_{c}=$ Surface runoff from the surrounding command areas into the command area $=0.397 \times 10^{6} \mathrm{~m}^{3} ; \mathrm{Q}=$ Runoff from the command area $=8.75 \times 10^{4} \mathrm{~m}^{3}$; and, $\mathrm{Qw}=0.042 \times 10^{6} \mathrm{~m}^{3}$ (Borehole discharge: total volume in year for water supply to Adigudem town, which is a town nearby to the reservoir, as computed from the gage).

Using Equation 13

$\mathrm{I}=\mathrm{P}+\mathrm{Qd}+\mathrm{Qs}+\mathrm{Q}^{-} \mathrm{ET}-\mathrm{Q}-\mathrm{Qw}=0.987 \times 10^{6} \mathrm{~m}^{3}$

\section{Recharge in Catchment}

The total amount of water which is actually available to recharge the groundwater circulation within the catchment is 4.065 million cubic meters. This amount of recharge is mainly due to the availability of the dam in the catchment.

Any application of water for irrigation from the reservoir should take into account this readily available water to avoid unnecessary increment in the level of groundwater that can cause soil problems in the catchment.

\section{Conclusions}

The Gumselasa catchment is semi-arid area where the $75.64 \%$ of the mean annual rainfall occurred in the two months of the rainy season of the year with very high concentration.

The rainy season has a total of three months. The recharge to the groundwater in the catchment was about $29.77 \%$ of the mean annual rainfall of the catchment, and any application of water for irrigation from the reservoir should take into account this readily available water.

\section{References}

[1] H. Bouwer, Groundwater Hydrology. New York: McGrawHill Book Company, 1978.

[2] R. S. Seyed, Y. Ismail, M. Saari, and S. Saghravani, "Estimating groundwater recharge using empirical method: A case study in the tropical zone," Sains Malaysiana, vol. 42, pp. 553-560, 2013.

[3] A. O'Grady, J. Carter, and K. Holland, "Review of Australian groundwater discharge studies of terrestrial systems. CSIRO: Water for a Healthy Country National Research Flagship, National Water Commission, Australia, 2010," p. 60, 2017.

[4] R. Dhungel and F. Fiedler, "Water balance to recharge calculation: Implications for watershed management using systems dynamics approach," Hydrology, vol. 3, p. 13, 2016.Available at: https://doi.org/10.3390/hydrology3010013.

[5] B. R. Scanlon, K. E. Keese, A. L. Flint, L. E. Flint, C. B. Gaye, W. M. Edmunds, and I. Simmers, "Global synthesis of groundwater recharge in semiarid and arid regions," Hydrological Processes, vol. 20, pp. 3335-3370, 2006.Available at: https://doi.org/10.1002/hyp.6335.

[6] B. R. Scanlon, R. W. Healy, and P. G. Cook, "Choosing appropriate techniques for quantifying groundwater recharge," Hydrogeology Journal, vol. 10, pp. 18-39, 2002.Available at: https://doi.org/10.1007/s10040-001-0176-2.

[7] Y. Xu and H. E. Beekman, "Groundwater recharge estimation in Southern Africa. UNESCO IHP Series No. 64, UNESCO Paris," p. $207,2003$.

[8] P. McMahon, L. Plummer, J. Böhlke, S. Shapiro, and S. Hinkle, "A comparison of recharge rates in aquifers of the United States based on groundwater-age data," Hydrogeology Journal, vol. 4, pp. 779-800, 2011.Available at: https://doi.org/10.1007/s100400 $11-0722-5$.

[9] S. Tyler, J. Chapman, S. Conrad, D. Hammermeister, D. Blout, J. Miller, M. Sully, and J. Ginanni, "Soil-water flux in the Southern Great Basin, United States: Temporal and spatial variations over the last 120,000 years," Water Resources Research, vol. 32, pp. 1481-1499, 1996.Available at: https://doi.org/10.1029/96wroo564.

[10] D. M. Wolock, Estimated mean annual natural groundwater recharge in the conterminous United States. Reston, VA, USA: U.S. Geological Survey, 2003.

[11] M. Anderson and W. Woessner, Applied groundwater modeling. San Diego: Academic, 1992.

[12] D. N. Lerner, A. S. Issar, and I. Simmers, Groundwater recharge: A guide to understanding and estimating natural recharge vol. 8. Hannover: Heise, 1990.

[13] B. Misstear, L. Brown, and P. Johnston, "Estimation of groundwater recharge in a major sand and gravel aquifer in Ireland using multiple approaches," Hydrogeology Journal, vol. 17, pp. 693-706, 2009.Available at: https://doi.org/10.1007/s 10040-008-0376-0.

[14] Y. Eyasu, G. Temesgen, G. E. Tesfa-Alem, M. Atinkut, F. Degol, H. Solomon, H. Abraham, v. S. Frank, and W. Flip, "Spate irrigation systems in Raya Valley (Ethiopia), Spate Irrigation Network, Overview Paper No. 13," 2012.

[15] Commission for Sustainable Agriculture and Environmental Rehabilitation in Tigray (COSAERT), "Preliminary assessment on the overall impact of dams, Mekele, Tigray, Ethiopia," 2001.

[16] J. Nyssen, J. Poesen, K. Descheemaeker, N. Haregeweyn, M. Haile, J. Moeyersons, A. Frankl, G. Govers, N. Munro, and J. Deckers, "Effects of region-wide soil and water conservation in semi-arid areas: The case of northern Ethiopia," Journal of Geomorphology, vol. 52, pp. 291-315, 2008.Available at: https://doi.org/10.1127/0372-8854/2008/0052-0291.

[17] G. Michiele, "Assessment of sources of salinity in Gumselasa irrigation scheme, Southern Tigray, Ethiopia," A Thesis Presented to the Department of Earth Sciences, Mekelle University, in Partial Fulfillment of the Requirements for the Degree of Master of Science (MSc), 2014. 
[18] T. Nata, T. Shishay, and T. Mekdes, "The water balance of May Nugus catchment, Tigray, Northern Ethiopia," International Journal of Earth Sciences and Engineering, vol. 3, pp. 609-625, 2010.

[19] International Organization of Standards (ISO), "ISO 1438-1 - Water flow measurement in open channels using weirs and venturi flumes - part 1: Thin-plate weirs, ISO,Geneva, Switzerland," 1980.

[20] G. Daniel, Aspects of climate and water budget in Ethiopia. Addis Ababa: Addis Ababa University Press, 1974.

[21] M. S. Elizabeth, Hydrology in practice, 3rd ed.: CRC Press, 1994.

[22] L. B. Leopold and T. Dunne, Water in environmental planning. San Francisco: W. H. Freeman and Company, 1978.

[23] S. K. Garg, Irrigation engineering and hydraulic structures. India: Khanna Publishers, 1987.

[24] R. Suresh, Soil and water conservation engineering, 4th ed. New Delhi: Standard Publishers Distributors, 2002. 